Article

\title{
The Novel Mechanisms Concerning the Inhibitions of Palmitate-Induced Proinflammatory Factor Releases and Endogenous Cellular Stress with Astaxanthin on MIN6 $\beta$-Cells
}

\author{
Atsuko Kitahara, Kazuto Takahashi *, Naru Morita, Toshitaka Murashima, Hirohisa Onuma, \\ Yoshikazu Sumitani, Toshiaki Tanaka, Takuma Kondo, Toshio Hosaka and Hitoshi Ishida \\ Third Department of Internal Medicine, Kyorin University School of Medicine, 6-20-2 Shinkawa, \\ Mitaka, Tokyo 181-8611, Japan; kitahara@ks.kyorin-u.ac.jp (A.K.); n-morita@ks.kyorin-u.ac.jp (N.M.); \\ mtosh@ka3.so-net.ne.jp (T.M.); onuma@ks.kyorin-u.ac.jp (H.O.); sumitani@ks.kyorin-u.ac.jp (Y.S.); \\ toshiaki@ks.kyorin-u.ac.jp (T.T.); takkon808@gmail.com (T.K.); toshio.hosaka@outlook.com (T.H.); \\ ishida@ks.kyorin-u.ac.jp (H.I.) \\ * Correspondence: kazuto_ta@ks.kyorin-u.ac.jp; Tel.: +81-422-47-5511 (ext. 3536); Fax: +81-422-76-6451
}

Received: 15 May 2017; Accepted: 14 June 2017; Published: 20 June 2017

\begin{abstract}
Astaxanthin, an antioxidant agent, can protect pancreatic $\beta$-cells of $\mathrm{db} / \mathrm{db}$ mice from glucotoxicity and resolve chronic inflammation in adipose tissue. Nonetheless, the effects of astaxanthin on free-fatty-acid-induced inflammation and cellular stress in $\beta$-cells remain to be demonstrated. Meanwhile, palmitate enhances the secretion of pro-inflammatory adipokines monocyte chemoattractant protein-1 (MCP-1) and vascular endothelial growth factor $\left(\mathrm{VEGF}_{120}\right)$. We therefore investigated the influence of astaxanthin on palmitate-stimulated MCP-1 and VEGF 120 secretion in mouse insulinoma (MIN6) pancreatic $\beta$-cells. Furthermore, whether astaxanthin prevents cellular stress in MIN6 cells was also assessed. Pre-treatment with astaxanthin or with $\mathrm{N}$-acetyl-cysteine (NAC) which is an antioxidant drug, significantly attenuated the palmitate-induced MCP-1 release through downregulation of phosphorylated c-Jun $\mathrm{NH}_{2}$-terminal protein kinase (JNK) pathways, and suppressed VEGF $_{120}$ through the PI3K/Akt pathways relative to the cells stimulated with palmitate alone. In addition, palmitate significantly upregulated homologous protein (CHOP) and anti-glucose-regulated protein (GRP78), which are endoplasmic reticulum (ER) stress markers, in MIN6 cells. On the other hand, astaxanthin attenuated the increased CHOP content, but further up-regulated palmitate-stimulated GRP78 protein expression. By contrast, NAC had no effects on either CHOP or GRP78 enhancement induced by palmitate in MIN6 cells. In conclusion, astaxanthin diminishes the palmitate-stimulated increase in MCP-1 secretion via the downregulation of JNK pathways in MIN6 cells, and affects VEGF $_{120}$ secretion through PI3K/Akt pathways. Moreover, astaxanthin can prevent not only oxidative stress caused endogenously by palmitate but also ER stress, which NAC fails to attenuate, via upregulation of GRP78, an ER chaperon.
\end{abstract}

Keywords: pancreatic $\beta$-cell; astaxanthin; palmitate

\section{Introduction}

Astaxanthin has potent antioxidant activity and is characterized by the basic structure of a carotenoid with keto and hydroxyl groups [1,2]. Because of this structure, extension of the conjugated system causes activation of astaxanthin as a radical sponge, and astaxanthin can exert both lipophilic and hydrophilic antioxidant activities. According to the studies examining the effects of the antioxidant activity of astaxanthin, it has a wide range of properties, including improvement of physical exercise capacity as evidenced by an anti-muscle fatigue effect and an endurance-enhancing 
effect $[3,4]$, prophylactic and curative effects on arteriosclerosis $[5,6]$, influences via activation of energy metabolism including that of lipids [7], and efficacy in the treatment of eye and skin disorders such as asthenopia [8,9] and inflammatory skin diseases [10].

In addition, because astaxanthin reportedly protects pancreatic $\beta$-cells of $\mathrm{db} / \mathrm{db}$ mice from glucotoxicity [11] and resolves chronic inflammation and insulin resistance in adipose tissue [12], there are high expectations about its potential clinical effects. Furthermore, astaxanthin has been confirmed to inhibit inflammation in the liver of high-fat-diet-fed mice [13], and the important finding that astaxanthin can ameliorate insulin resistance induced by TNF- $\alpha$ and palmitate in L6 myoblasts has also been demonstrated [14]. Nevertheless, the effects of astaxanthin on free fatty acid-induced inflammation and cellular stress in pancreatic $\beta$-cells remain as yet unknown.

Furthermore, monocyte chemoattractant protein-1 (MCP-1) and vascular endothelial growth factor (VEGF) have been confirmed to play central roles in the chronic inflammation in obese adipose tissue, which are the main contributors to insulin resistance [15-19]. It has also been demonstrated that secretion of MCP-1 and VEGF increases in palmitate-yielded hypertrophic 3T3-L1 adipocytes thus mimicking the hyperlipidemia frequently complicating type 2 diabetes mellitus [20]. MCP-1 secreted by hypertrophic adipocytes appears to induce recruitment of macrophages to obese adipose tissue, in which chronic inflammation may consequently be triggered [21,22]. In addition, the increased VEGF secretion by hypertrophic adipocytes has been found to augment the recruitment of macrophages into adipose tissue through enhanced angiogenesis [23]. Moreover, experimentation with $\mathrm{db} / \mathrm{db}$ mice, an obese model of diabetes mellitus, has verified that administration of an antibody neutralizing VEGF inhibits not only angiogenesis but also adipogenesis, and macrophage recruitment into obese adipose tissue [23]. However, the dynamics of MCP-1 and VEGF secretion from pancreatic $\beta$-cells and the induction of chronic inflammation in islets of Langerhans in a hyperlipidemic state are essentially unknown at present.

Thus, in this study, using mouse insulinoma (MIN6) cells, we elucidated the mechanism downregulated by astaxanthin on the palmitate-induced enhancement of either MCP-1 mRNA expression and protein secretion or alternatively production of spliced $\mathrm{VEGF}_{120}$ lacking a heparin-binding domain [20], which are key factors of induction of chronic inflammation. Furthermore, we assessed the effects of astaxanthin on cellular stress, e.g., endogenous oxidative stress and endoplasmic reticulum (ER) stress, caused by palmitate in MIN6 cells.

\section{Results}

\subsection{Palmitate Augments MCP-1 and VEGF 120 Secretion by MIN6 Cells}

Palmitate markedly increased MCP-1 secretion by 1.3-fold in the analysis by western blotting $(p$ $<0.01$; Figure 1A). In addition, $\mathrm{VEGF}_{120}$ release was enhanced 1.6-fold by treatment with palmitate $(p<0.01$; Figure 1B). As shown in Figure 1D,E, MCP-1 mRNA expression was increased 1.3-fold by palmitate $(p<0.01)$, and VEGF-A including VEGF 120 was upregulated 1.4-fold $(p<0.01)$. Meanwhile, palmitate had no effect on IL-10 release (Figure 1C). 


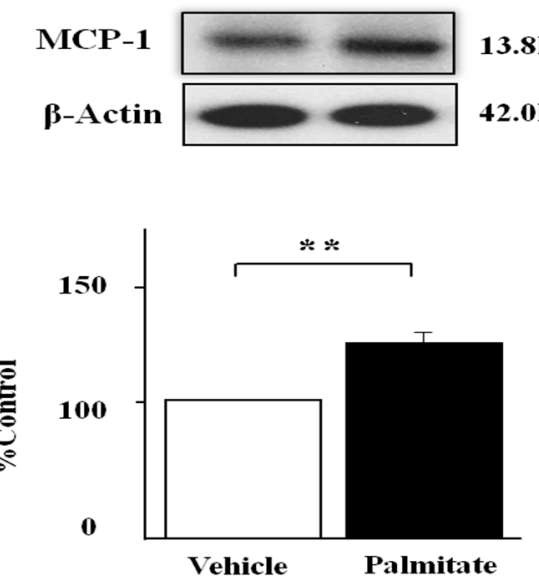

(A)
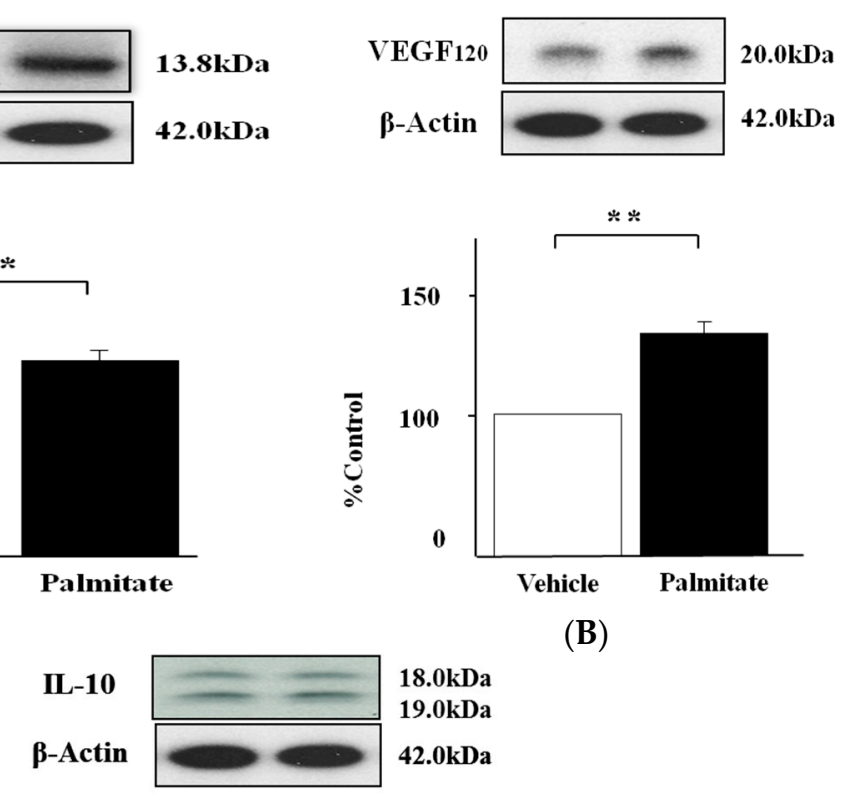

(B)

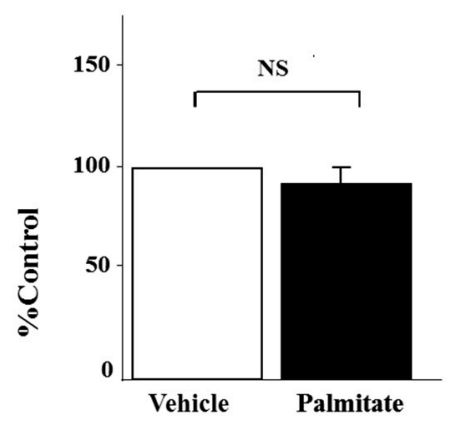

(C)

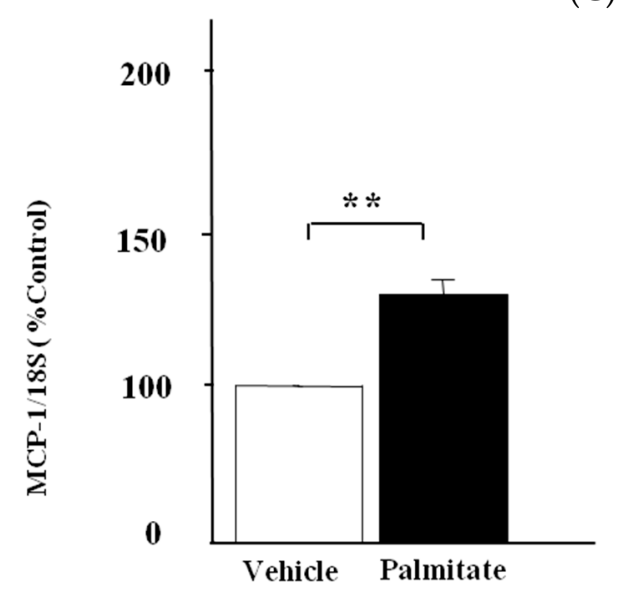

(D)

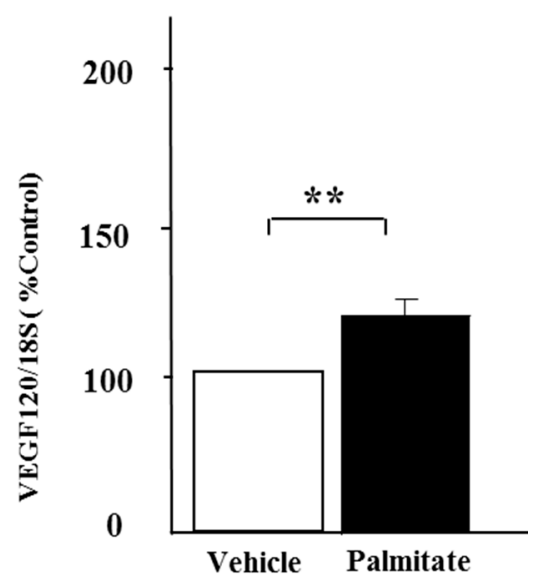

(E)

Figure 1. Cytokine release and expression levels on palmitate-stimulated MIN6 $\beta$-cells. MIN6 cells were stimulated with $0.3 \mathrm{mmol} / \mathrm{L}$ palmitate or ethanol vehicle alone for either $6 \mathrm{~h}$ ( $\mathbf{D}$ and $\mathbf{E})$ or $24 \mathrm{~h}$ (A, B and C). MCP-1 (A), VEGF 120 (B) and IL-10 (C) secretion by MIN6 cells was quantified by immunoblot analysis. $\beta$-Actin served as an internal control. (A-C) top: representative pictures of immunoblotting that was quantified. The mRNA levels of MCP-1 (D) and VEGF-A (E) including VEGF $_{120}$ were measured by quantitative real-time RT-PCR. The mRNA signal for each gene was normalized to the $18 \mathrm{~S}$ rRNA signal. Results are mean $\pm \operatorname{SEM}(n=4) ;{ }^{* *} p<0.01$ compared to vehicle. NS; no significant difference compared to vehicle. 


\subsection{Astaxanthin Reverses Palmitate-Induced Enhancement of MCP-1 and VEGF 120 Secretion}

We tested whether the treatment with astaxanthin could affect MCP-1 and VEGF 120 expression in MIN6 cells treated with palmitate. Pre-treatment with astaxanthin significantly diminished the release of MCP-1 by $33 \%$ and $\mathrm{VEGF}_{120}$ by $30 \%$ relative to the cells stimulated with palmitate alone $(p<0.05$, respectively; Figure 2A,C). On the other hand, there were no significant changes in MCP-1 and $\mathrm{VEGF}_{120}$ release under the influence of astaxanthin treatment alone (Figure 2A,C). Furthermore, the significant enhancement of both MCP-1 and VEGF-A (including VEGF 120 ) mRNA expression by treatment with palmitate was attenuated by astaxanthin by $18 \%$ and $34 \%$, respectively $(p<0.01$; Figure 2B,D). In contrast, astaxanthin alone failed to increase MCP-1 and VEGF-A mRNA expression (Figure 2B,D).

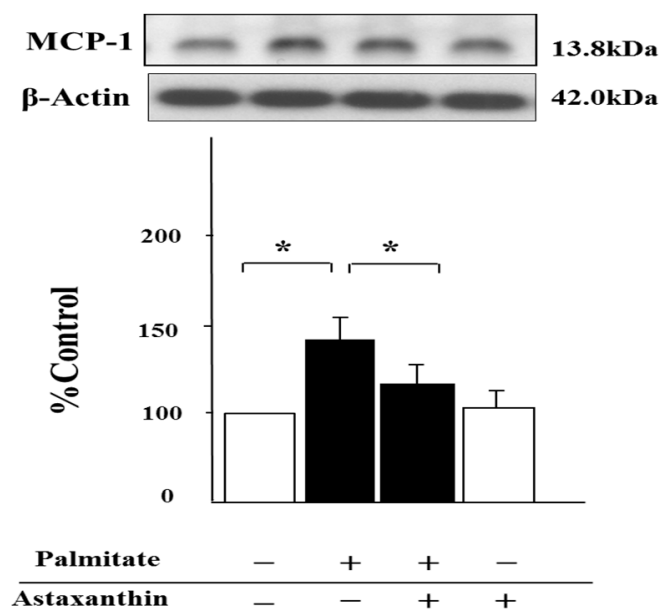

(A)

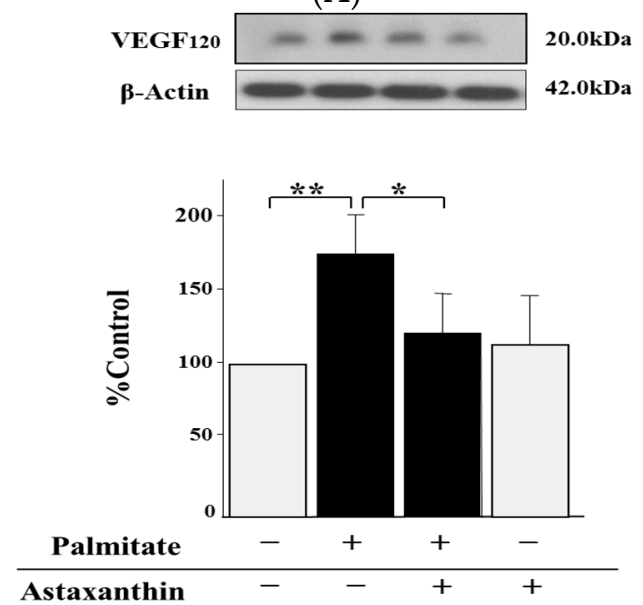

(C)
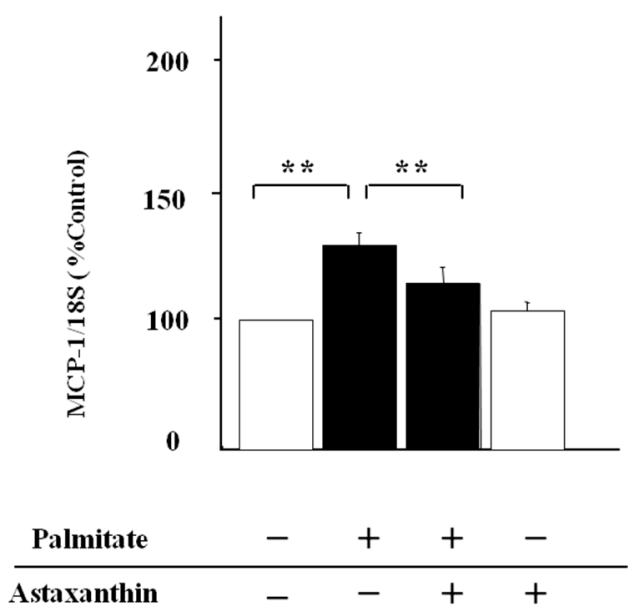

(B)

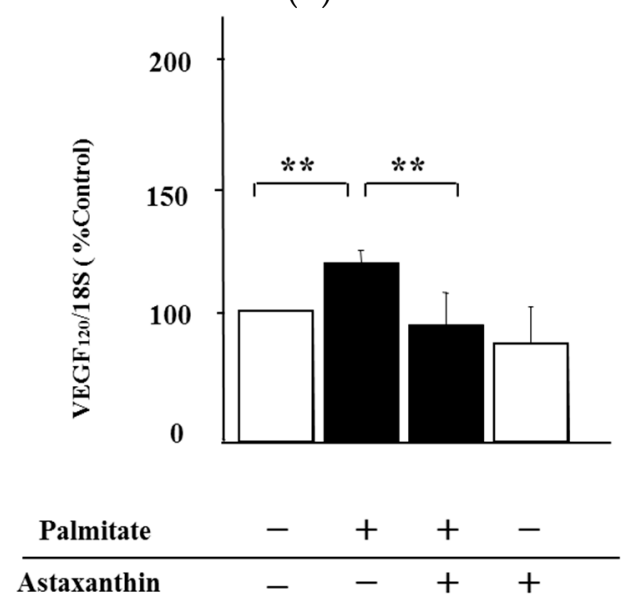

(D)

Figure 2. Astaxanthin reverses MCP-1 and $\mathrm{VEGF}_{120}$ upregulation by palmitate. MIN6 $\beta$-cells were pretreated with $10 \mu \mathrm{mol} / \mathrm{L}$ astaxanthin for $20 \mathrm{~min}$, and then these cells were treated with $0.3 \mathrm{mmol} / \mathrm{L}$ palmitate for either $6 \mathrm{~h}$ (B and D) or $24 \mathrm{~h}$ (A and C), with or without astaxanthin. MCP-1 (A) and $\mathrm{VEGF}_{120}(\mathbf{C})$ secretion was analyzed by quantitative immunoblots. MCP-1 (B) and VEGF 120 (D) mRNA expression levels were measured by real-time PCR. $\beta$-Actin was assessed as an internal control. (A) and (C) top: representative pictures of immunoblotting that was quantified. The mRNA signal for each gene was normalized to the $18 \mathrm{~S}$ rRNA signal. Results are mean $\pm \operatorname{SEM}(\mathrm{n}=4) ;{ }^{*} p<0.05 ;{ }^{* *} p<0.01$ compared to the corresponding controls. 


\subsection{NAC, an Antioxidant Agent, Can Inhibit Palmitate-Stimulated MCP-1 and VEGF 120 Secretion}

NAC lowered the palmitate-induced increase of the MCP-1 release by $22 \%$ compared with MIN6 cells exposed to palmitate alone ( $p<0.01$; Figure 3A). Moreover, the enhancement of VEGF 120 secretion by the stimulation with palmitate was reduced by NAC treatment by $27 \%(p<0.01$; Figure 3B).

On the other hand, treatment with NAC alone was unable to influence either MCP-1 or VEGF 120 secretion (Figure 3A,B).

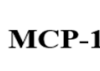

B-Actin

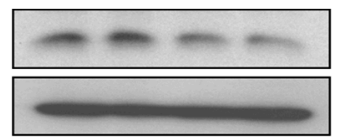

$13.8 \mathrm{kDa}$

$42.0 \mathrm{kDa}$

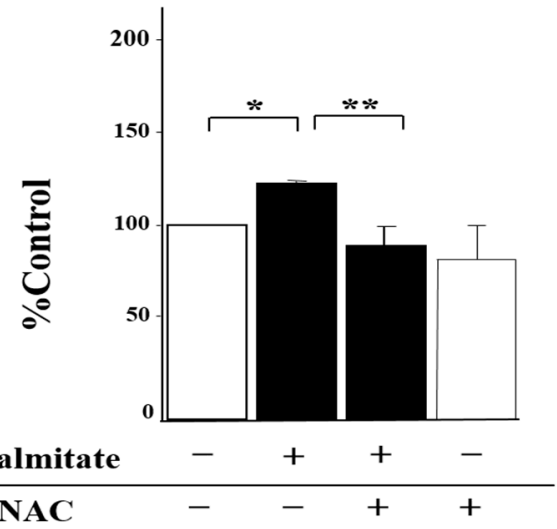

(A)
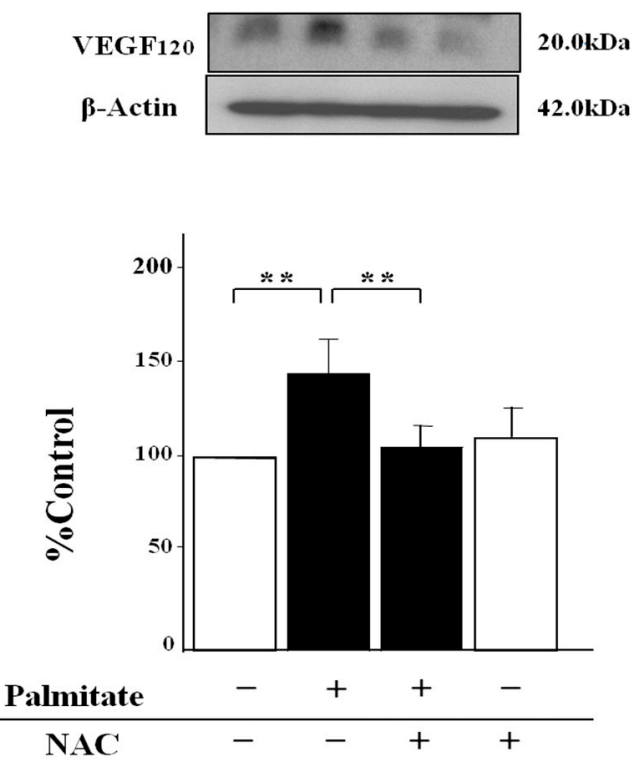

(B)

Figure 3. NAC reduces palmitate-induced MCP-1 and $\mathrm{VEGF}_{120}$ release from MIN6 cells. MIN6 cells were pretreated with $1 \mathrm{mmol} / \mathrm{L}$ NAC or vehicle (dimethyl sulfoxide) for $20 \mathrm{~min}$, and then these cells were treated with $0.3 \mathrm{mmol} / \mathrm{L}$ palmitate for $24 \mathrm{~h}$ with or without NAC. MCP-1 (A) or VEGF 120 (B) secretion was measured by quantitative immunoblots. $\beta$-Actin served as an internal control. (A and $\mathbf{B})$ top: representative pictures of immunoblotting that was quantified. Results are mean \pm SEM $(n=4)$; * $p<0.05 ;{ }^{* *} p<0.01$ compared to the corresponding controls.

\subsection{Astaxanthin Can Inhibit Oxidative Stress}

The intracellular concentration of hydroperoxides, a marker of endogenous oxidative stress, in cells treated with palmitate was augmented 2.5-fold ( $p<0.01$; Figure $4 \mathrm{~A})$. In contrast, astaxanthin was able to attenuate this upregulation of hydroperoxides by $30 \%$ compared with palmitate-stimulated cells $\left(p<0.01\right.$; Figure 4A). Meanwhile, exogenous $\mathrm{H}_{2} \mathrm{O}_{2}$ increased the MCP-1 release 1.4-fold $(p<0.01$; Figure $4 \mathrm{~B}$ ), and the pre-treatment with astaxanthin suppressed this effect by $30 \%$ relative to MIN6 cells treated with $\mathrm{H}_{2} \mathrm{O}_{2}$ alone ( $p<0.01$; Figure $\left.4 \mathrm{~B}\right)$.

As with MCP-1, astaxanthin also decreased $\mathrm{VEGF}_{120}$ secretion by $30 \%(p<0.01$; Figure $4 \mathrm{C})$, whereas $\mathrm{H}_{2} \mathrm{O}_{2}$ alone clearly enhanced this section 1.3-fold ( $p<0.01$; Figure $4 \mathrm{C}$ ). 


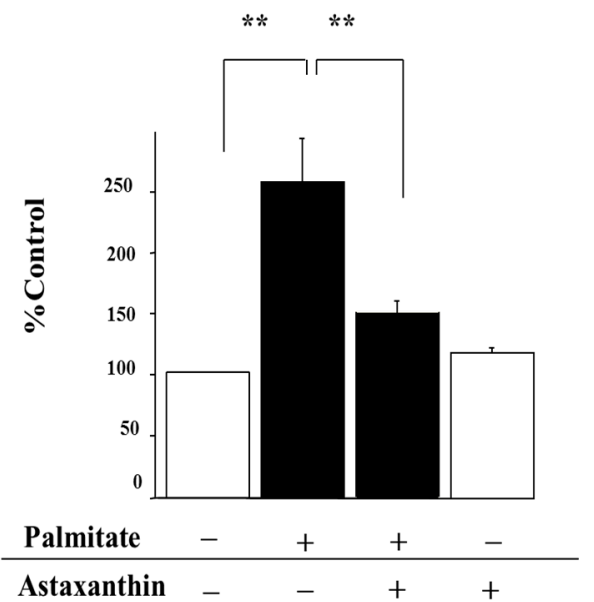

(A)
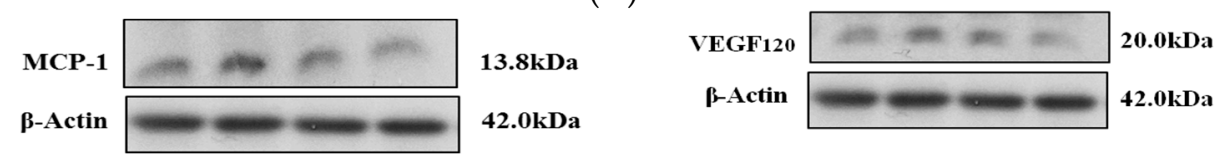

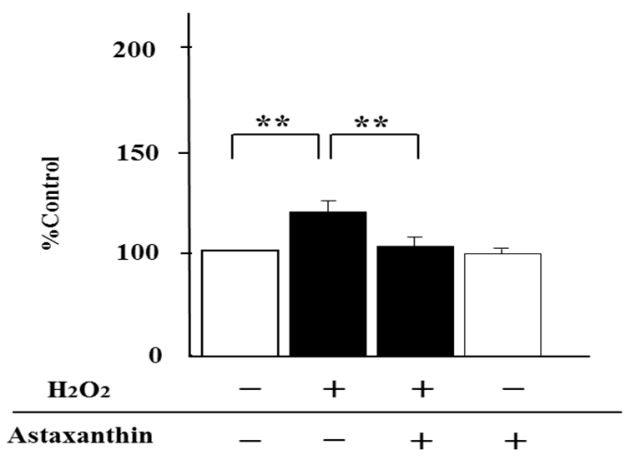

(B)

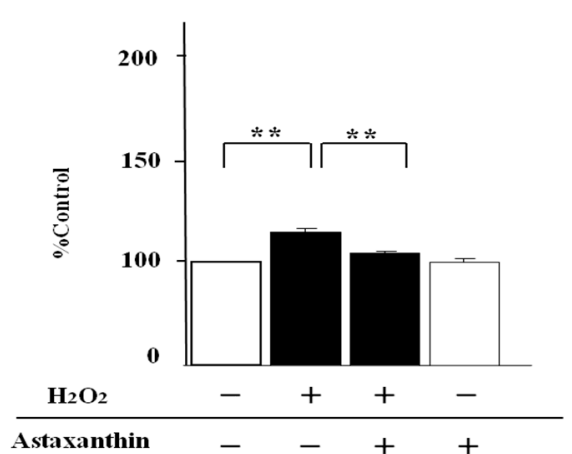

(C)

Figure 4. Astaxanthin attenuates palmitate-induced upregulation of hydroperoxides and the release of both MCP-1 and VEGF 120 increased by $\mathrm{H}_{2} \mathrm{O}_{2}$. MIN6 $\beta$-cells pretreated with $10 \mu \mathrm{mol} / \mathrm{L}$ astaxanthin for $20 \mathrm{~min}$ were stimulated with $0.3 \mathrm{mmol} / \mathrm{L}$ palmitate (A) or $300 \mathrm{ng} / \mathrm{mL} \mathrm{H}_{2} \mathrm{O}_{2}$ (B and C) for $24 \mathrm{~h}$. Hydroperoxide content in MIN6 cells was measured by means of the Free Radical Elective Evaluator system $(\mathbf{A})$. Results are mean \pm SEM $(n=4)$. The release of MCP-1 $(\mathbf{B})$ and VEGF $_{120}(\mathbf{C})$ was quantified by immunoblot analysis. $\beta$-Actin was assessed as an internal control. (B) and (C) top: representative pictures of immunoblotting that was quantified. Results are mean $\pm \operatorname{SEM}(n=4) ;{ }^{* *} p<0.01$ compared to the corresponding controls.

\subsection{The MCP-1 Release by MIN6 Cells Treated with Palmitate Is Increased via JNK Pathways}

Next, we determined whether MAPKs pathways are involved in the MCP-1 release. The treatment with JNK inhibitor SP600125 $(10 \mu \mathrm{mol} / \mathrm{L})$ significantly reduced the increased MCP-1 secretion by $38 \%$ relative to the cells stimulated with palmitate alone ( $p<0.05$; Figure $5 \mathrm{~A})$. On the other hand, SP600125 had no effects on palmitate-induced enhancement of VEGF $_{120}$ secretion (Figure 5B).

Moreover, we evaluated phosphorylation levels of JNK. JNK phosphorylation on Thr183/Tyr185 was significantly increased 1.6 -fold by treatment with palmitate $(p<0.01$; Figure $5 \mathrm{C})$. However, SP600125 significantly attenuated the palmitate-stimulated JNK phosphorylation by $25 \%,(p<0.01$; Figure 5C), and astaxanthin as well as the SP600125 also inhibited the enhanced JNK phosphorylation by $24 \%(p<0.01$; Figure 5D). Meanwhile, astaxanthin alone had no effects on JNK phosphorylation (Figure 5D). 


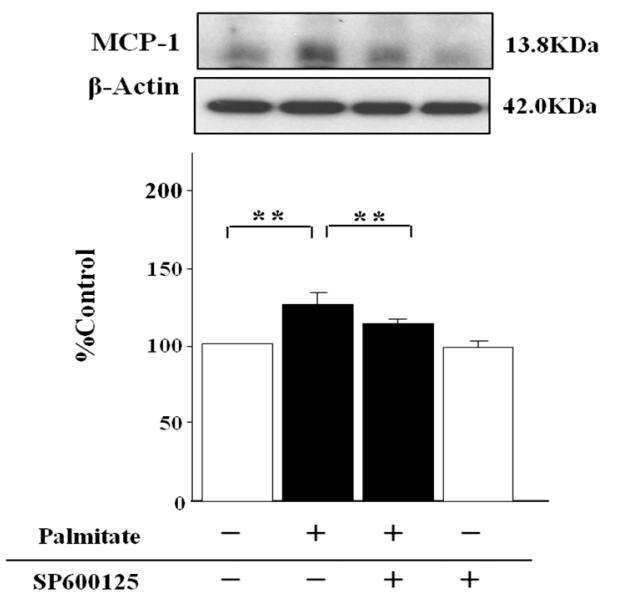

(A)
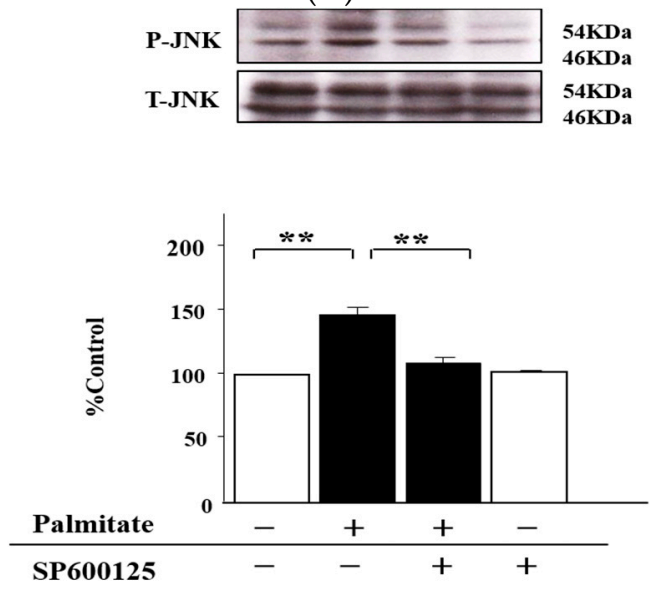

(C)
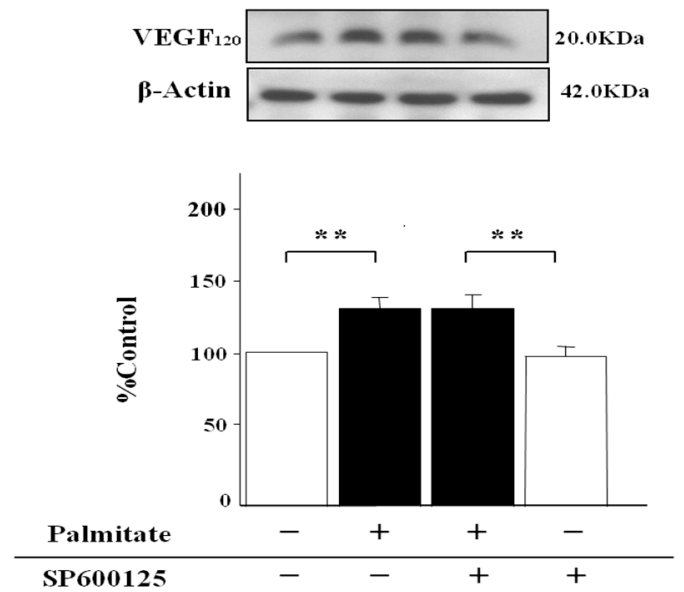

(B)
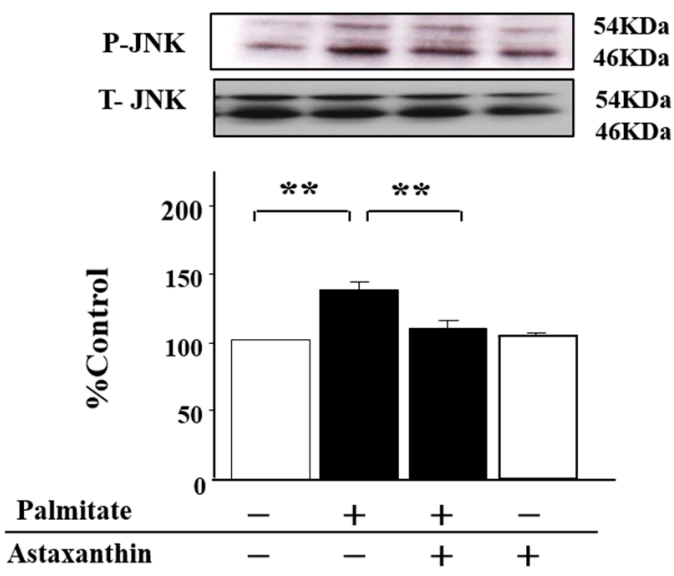

(D)

Figure 5. The MCP-1 release from MIN6 cells is enhanced via JNK, but the JNK pathway is unrelated to VEGF $_{120}$ secretion. MIN6 cells were pretreated with $10 \mu \mathrm{mol} / \mathrm{L}$ SP600125, $10 \mu \mathrm{M}$ astaxanthin, or vehicle (dimethyl sulfoxide) alone for $20 \mathrm{~min}$. Then, the cells were incubated with $0.3 \mathrm{mmol} / \mathrm{L}$ palmitate or vehicle (ethanol) alone for $24 \mathrm{~h}$ with or without either SP600125 (A, B and C) or astaxanthin (D). MCP-1 secretion (A) and $\mathrm{VEGF}_{120}$ secretion (B) were then quantified by immunoblotting with $\beta$-actin as an internal control. JNK phosphorylation on Thr183/Tyr185 (C and D) was also quantified by immunoblot analysis. Phospho-JNK was normalized to total JNK protein. (A-D) top: representative pictures of immunoblotting that was quantified. Results are mean $\pm \operatorname{SEM}(n=4) .{ }^{* *} p<0.05 ;{ }^{* *} p<0.01$ compared to the corresponding controls.

\subsection{Palmitate Upregulates VEGF 120 Secretion via PI3K Pathways}

To examine the signaling pathways involved in the palmitate-stimulated increase of $\mathrm{VEGF}_{120}$ secretion, we used LY294002, an inhibitor of phosphatidylinositol 3-kinase (PI3K), which has been reported to repress $\mathrm{VEGF}_{120}$ release by adipocytes [23]. LY294002 markedly diminished the palmitate-induced increase of $\mathrm{VEGF}_{120}$ secretion from MIN6 cells by $27 \%(p<0.01$; Figure 6A). Nonetheless, there were no effects of treatment with LY294002 on palmitate-induced MCP-1 increase (Figure 6B). In addition, LY294002 was obviously able to attenuate Akt phosphorylation on Ser473, which was augmented by the treatment with palmitate, by $30 \%(p<0.01$; Figure 6C). As with LY294002, astaxanthin inhibited the enhancement of Akt phosphorylation with the exposure of palmitate by $20 \%$ $(p<0.01$; Figure 6D). However, astaxanthin alone failed to impact the Akt phosphorylation (Figure 6D). 

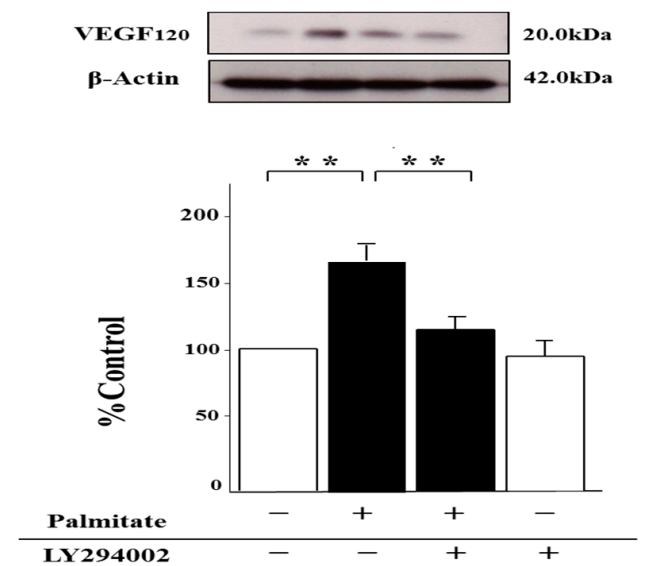

(A)
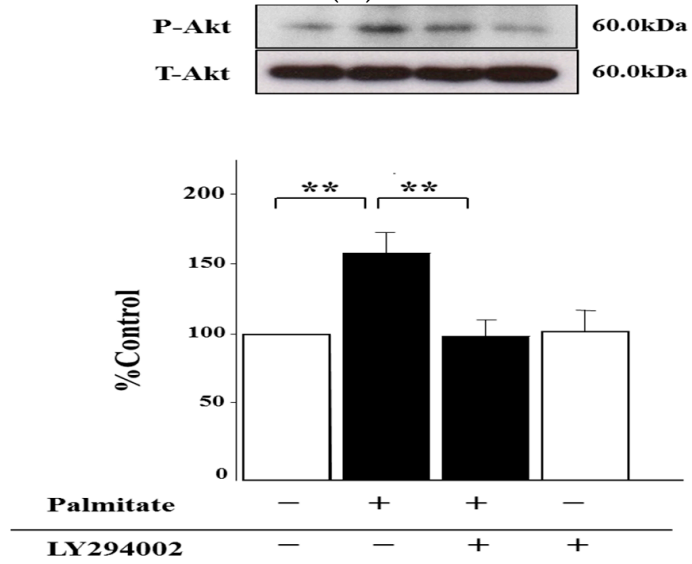

(C)
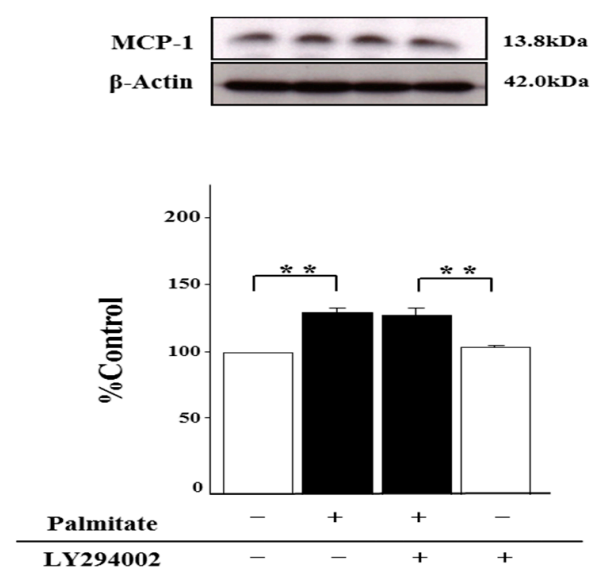

(B)
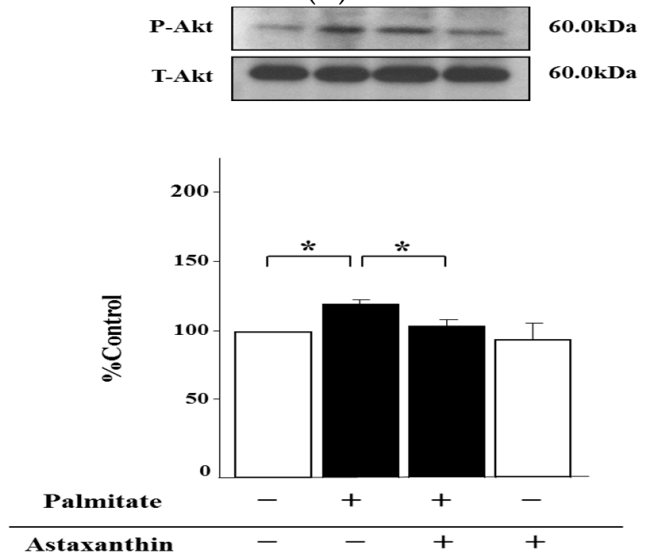

(D)

Figure 6. Involvement of PI3K (phosphatidylinositol 3-kinase) pathways in $\mathrm{VEGF}_{120}$ secretion by MIN6 $\beta$-cells. MIN6 cells were pretreated with $50 \mu \mathrm{mol} / \mathrm{L} \mathrm{LY294002,} 10 \mu \mathrm{mol} / \mathrm{L}$ astaxanthin, or vehicle (dimethyl sulfoxide) alone for $20 \mathrm{~min}$. Then, the cells were stimulated with $0.3 \mathrm{mmol} / \mathrm{L}$ palmitate or vehicle (ethanol) alone for $24 \mathrm{~h}$ with or without either LY294002 (A, B and C) or astaxanthin (D). $\operatorname{VEGF}_{120}(\mathbf{A})$ and MCP-1 secretion (B) was analyzed by immunoblotting. $\beta$-Actin was assessed as an internal control. Akt phosphorylation on Ser473 under the influence of LY294002 or astaxanthin is shown in (C) and (D) as immunoblotting. Phospho-Akt was normalized to total Akt protein. (A-D) top: representative pictures of immunoblotting that was quantified. Results are mean \pm SEM $(n=4)$; * $p<0.05 ;{ }^{* *} p<0.01$ compared to the corresponding controls.

\subsection{Astaxanthin Can Eliminate ER Stress via the Enhancement of GRP78 Expression}

Moreover, we tested whether astaxanthin has effects against ER stress. Palmitate significantly upregulated CHOP, 3.6 and 2.7-fold, ( $p<0.01$; Figure 7A,B), and GRP78.

1.3 and 1.2-fold, $(p<0.01$; Figure 7C,D), which are ER stress markers, in MIN6 cells. On the other hand, astaxanthin was able to attenuate the palmitate-stimulated increase in CHOP content by $36 \%(p<0.01$; Figure 7A), but alone had no effect on CHOP (Figure 7A). NAC failed to inhibit palmitate-stimulated upregulation of CHOP and GRP78 in MIN6 cells (Figure 7B,D). Contrary to CHOP content, the reinforcement of GRP78 by palmitate was further increased 1.2-fold by astaxanthin $(p<0.01$; Figure 7C), and then astaxanthin treatment alone also increased the GRP78 content 1.3-fold ( $p<0.01$; Figure 7C). Accordingly, we explored the influence of astaxanthin on GRP78 mRNA expression. This expression was markedly enhanced 1.2-fold by treatment with astaxanthin $(p<0.01$; Figure 7E). Furthermore, the palmitate-stimulated upregulation of GRP78 mRNA was increased 1.2-fold by astaxanthin $(p<0.01$; Figure 7E). 


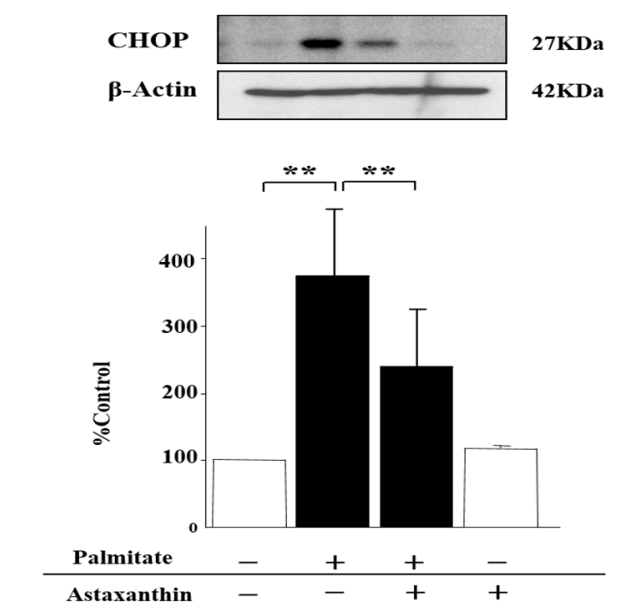

(A)

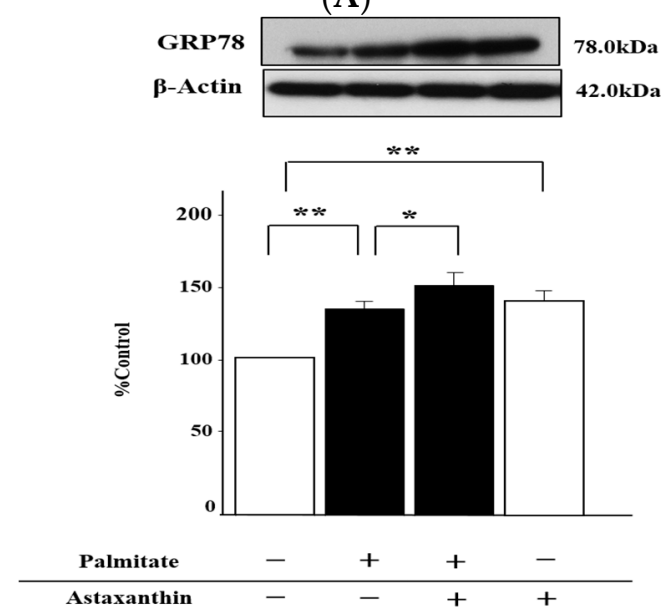

(C)
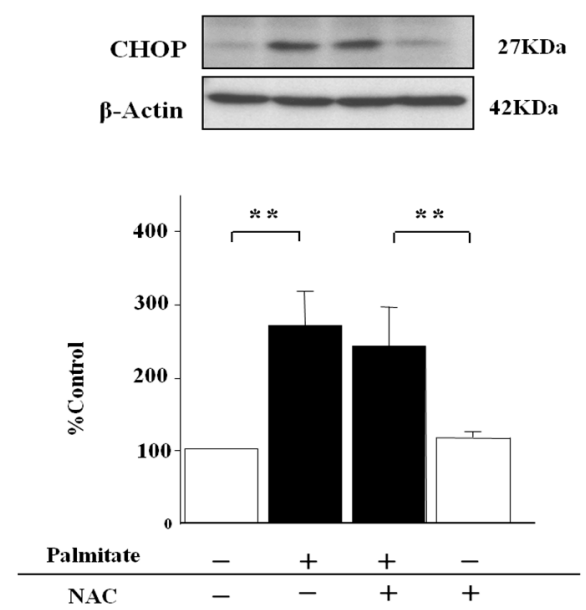

(B)
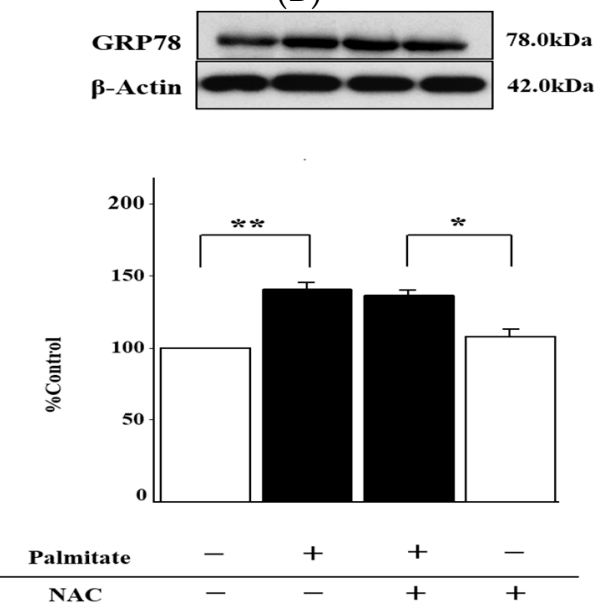

(D)

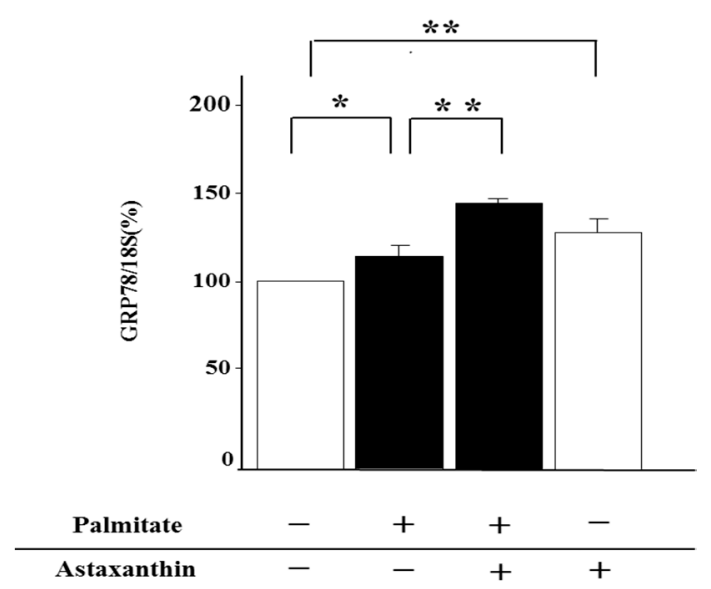

(E)

Figure 7. Astaxanthin diminished ER stress via the increase of GRP78, but NAC cannot, in MIN6 cells. MIN6 cells were pretreated with $10 \mu \mathrm{mol} / \mathrm{L}$ astaxanthin (A, C and E), $1 \mathrm{mM} \mathrm{NAC} \mathrm{(B} \mathrm{and} \mathrm{D),} \mathrm{or} \mathrm{vehicle}$ (dimethyl sulfoxide) alone for $20 \mathrm{~min}$. Then, the cells were incubated with $0.3 \mathrm{mmol} / \mathrm{L}$ palmitate or vehicle (ethanol) alone for $24 \mathrm{~h}$. CHOP (A and B) and GRP78 contents (B and D) were measured by immunoblotting. $\beta$-Actin served as an internal control. (A)-(D) top: representative pictures of immunoblotting that was quantified. The GRP78 mRNA level (E) was assessed using Digital PCR System. The mRNA signal was normalized to the $18 \mathrm{~S}$ rRNA signal. Results are mean \pm SEM $(\mathrm{n}=4)$; * $p<0.05 ;{ }^{* *} p<0.01$ compared to the corresponding controls. 


\section{Discussion}

Palmitate reportedly causes cellular dysfunction in pancreatic $\beta$-cells [24,25], and MCP-1 and VEGF have been confirmed to promote chronic inflammation by recruiting macrophages into hypertrophic adipose tissue. Furthermore, in our previous study, we have demonstrated that 3T3-L1 adipocytes stimulated with palmitate increase the secretion of MCP-1 and VEGF ${ }_{120}$ [20].

Thus, we first examined palmitate effects on mRNA expression and secretion of both MCP-1 and VEGF $_{120}$ in $\beta$-cells. Stimulation with palmitate led to significant increases in MCP-1 mRNA expression and secretion in MIN6 cells, as was the case for VEGF 120 . These results indicate that palmitate controls the expression levels of MCP-1 and VEGF 120 at the transcription level.

According to all these results, palmitate increases the secretion of $\mathrm{VEGF}_{120}$, so that angiogenesis in the islets of the pancreas can be enhanced. Additionally, on the basis of this angiogenesis, the increase in palmitate-stimulated MCP-1 release by $\beta$-cells is able to induce macrophage infiltration into the islets; this process might consequently trigger inflammation in these islets and ultimately cause pancreatic $\beta$-cell dysfunction.

On the other hand, astaxanthin clearly reduced both MCP-1 and VEGF 120 mRNA expression and release which had been significantly increased by palmitate. According to these results, we can hypothesize that palmitate enhances both the secretion of MCP- 1 and $\mathrm{VEGF}_{120}$ by $\beta$-cells and induces macrophage infiltration into the islets of pancreas, which might consequently trigger inflammation in these islets and ultimately cause pancreatic $\beta$-cell dysfunction. In contrast, astaxanthin appears to protect $\beta$-cells from this damage, the dysfunction of $\beta$-cells, by suppressing the palmitate-induced release of MCP-1 and VEGF 120 .

Next, because we had previously demonstrated that palmitate augments MCP-1 and VEGF 120 release by increasing oxidative stress in adipocytes [20], the effects of palmitate and astaxanthin on cellular stress in $\beta$-cells were examined. Although palmitate increased oxidative stress, which is a major form of cellular stress, in MIN6 cells, the antioxidant astaxanthin, as expected, attenuated the oxidative stress that had been increased by palmitate. In addition, hydrogen peroxide, which is one of the reactive oxygen species (ROS), enhanced both MCP-1 and VEGF 120 secretion by MIN6 cells. On the other hand, astaxanthin as well as NAC, another major antioxidant agent, can apparently inhibit the palmitate-induced increase in the MCP- 1 and $\mathrm{VEGF}_{120}$ release by attenuating oxidative stress. Accordingly, we can theorize that astaxanthin can reduce the MCP-1 and VEGF 120 release by diminishing oxidative stress, whereas palmitate enhances, though only partially, the secretion of MCP-1 and VEGF 120 through increasing oxidative stress.

In addition, we verified the involvement of the JNK and PI3K/Akt pathways, which are intracellular signal transduction pathways acting downstream of oxidative stress [26,27]. The increase of MCP-1 secretion in response to stimulation with palmitate was significantly reduced by the treatment with SP600125, a JNK-specific inhibitor, but there were no effects of the treatment with LY294002, an inhibitor of PI3K/Akt, on the palmitate-induced MCP-1 release. Additionally, the phosphorylation of JNK augmented by palmitate was also clearly attenuated by both astaxanthin and SP600125. Given these results, we supposed that palmitate activates the JNK pathways probably by increasing oxidative stress, thereby enhancing theMCP-1 release. On the contrary, $\mathrm{VEGF}_{120}$ secretion reinforced by palmitate was repressed by LY294002, while SP600125 had no effect on the palmitate-stimulated increase in the $\mathrm{VEGF}_{120}$ release. Moreover, the enhanced phosphorylation of Akt, which was caused by the treatment with palmitate, was significantly diminished by astaxanthin and LY294002. Therefore, palmitate may activate PI3K/Akt pathways via augmenting oxidative stress no less than palmitate can activate the JNK pathway, which is involved in the MCP-1 release, thus resulting in the increase of VEGF $_{120}$ secretion. 
Furthermore, besides oxidative stress, analyzed the effects of astaxanthin on ER stress, the other major cellular stress. Although it has previously been suggested that astaxanthin may attenuate ER stress in the liver [28], its effects on pancreatic $\beta$-cell stress remain to be elucidated. Palmitate, a saturated fatty acid, exacerbated ER stress, as well as oxidative stress, in MIN6 cells as previously reported [29-32]. Interestingly, an antioxidant, NAC, failed to suppress the ER stress enhanced by palmitate, whereas astaxanthin, another antioxidant, attenuated this enhancement of ER stress in addition to oxidative stress. This result suggests that astaxanthin not only has an antioxidant function but also broadly exerts anti-cellular-stress actions. We further investigated the mechanisms underlying this action. Palmitate enhanced the expression levels of CHOP and GRP78, which are ER stress markers [33,34]. Astaxanthin significantly suppressed palmitate-enhanced CHOP protein expression but further upregulated palmitate-induced GRP78. These data show that astaxanthin can promote correction of the folding of abnormal proteins that have been elevated by palmitate treatment and can attenuate ER stress by enhancing the expression of GRP78, which is an ER chaperone [35]. Astaxanthin is, therefore, likely to suppress palmitate-enhanced CHOP expression but to enhance GRP78 expression. Concerning this upregulation of GRP78 stimulated with astaxanthin, it seems that our study is the first report of this phenomenon. ER stress may be apt to happen due to lipotoxicity in MIN6 cells, because $\beta$-cells are more vulnerable to cellular stress [36,37]. Nonetheless, further studies may need to be conducted focusing on this issue, including associated transcription factors.

In conclusion, this study is the first to demonstrate that astaxanthin inhibits the secretion of MCP-1 and $\mathrm{VEGF}_{120}$ by pancreatic $\beta$-cells; these proteins are increased in the hyperlipidemic state frequently associated with type 2 diabetes mellitus. Consequently, it is likely that astaxanthin relieves chronic inflammation of the pancreas and prevents pancreatic $\beta$-cell damage. Moreover, this study confirmed that increased MCP-1 secretion by $\beta$-cells in the hyperlipidemic state is involved in the reinforcement of oxidative stress and of JNK pathways activated by this oxidative stress. It was also demonstrated that hyperlipidemia-stimulated VEGF $_{120}$ secretion by pancreatic $\beta$-cells is associated with oxidative stress, and PI3K/Akt pathways are activated downstream of the oxidative stress. Accordingly, it appears that astaxanthin inhibits activation of both JNK and PI3K/Akt pathways by attenuating oxidative stress, so that increased secretion of MCP-1 and VEGF 120 by $\beta$-cells in the hyperlipidemic state is suppressed, ultimately preventing pancreatic $\beta$-cell damage (Figure 8 ).

In addition, because astaxanthin may reduce ER stress, as well as oxidative stress, by enhancing GRP78 expression in $\beta$-cells, we can reasonably suppose that astaxanthin functions as more than a mere antioxidant agent and exert an anti-cellular-stress action against a wide range of cellular stresses. Thus, astaxanthin can be regarded as a potentially important factor that not only prevents pancreatic $\beta$-cell damage through antioxidative action, but also eliminates various types of cellular stress and thereby broadly protects pancreatic $\beta$-cells and islets (Figure 8 ). Presumably, astaxanthin may play an important role in the treatment of diabetes mellitus and hyperlipidemia by restoring insulin secretion and insulin sensitivity. Additionally, this possibility seems to merit further research aimed at utilizing this compound as a preventive pharmacotherapy in the future practice. 


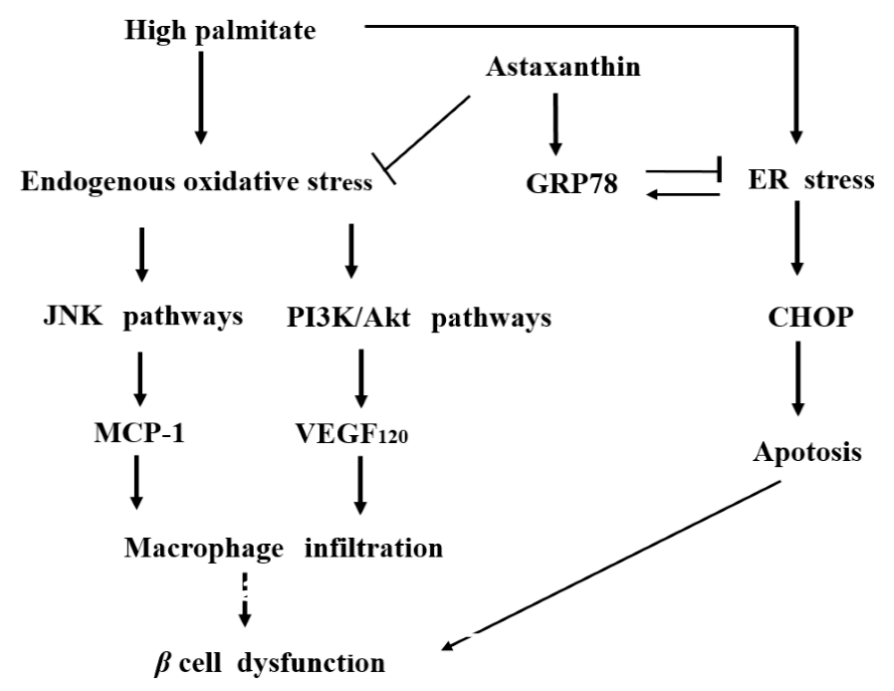

Figure 8. The schema of putative mechanisms behind endogenous MCP-1 and VEGF-induced low-grade chronic inflammation and insulin resistance in pancreatic $\beta$-cells in vivo, and of prevention thereof by astaxanthin. High concentration of palmitate increases endogenous oxidative stress, allowing for the MCP-1 release to be enhanced through the JNK pathways activated by oxidative stress; $\mathrm{VEGF}_{120}$ release from these cells nevertheless can be upregulated via activation of distinct signaling of the $\mathrm{PI} 3 \mathrm{~K} /$ Akt pathways. Moreover, the increase of palmitate-stimulated MCP-1 and $\mathrm{VEGF}_{120}$ release by $\beta$-cells can induce macrophage infiltration and causes pancreatic $\beta$-cell dysfunction. Astaxanthin inhibits the palmitate-increased MCP- 1 and $\mathrm{VEGF}_{120}$ secretion through the attenuation of endogenous oxidative stress and its downstream JNK and PI3K/Akt activation, resulting in prevention of $\beta$-cell dysfunction induced by palmitate. In addition, palmitate enhances ER stress, which is manifested as enhancement of CHOP and GRP78 expression. On the other hand, astaxanthin reduces this CHOP augmentation, but further upregulates GRP78; therefore, astaxanthin can protect cells from ER stress-mediated apoptosis and subsequently also prevent $\beta$-cell dysfunction.

\section{Materials and Methods}

\subsection{Reagents}

XF Palmitate-BSA FAO Substrate was purchased from Seahorse Bioscience (North Billerica, MA, USA), and astaxanthin was obtained from Fuji Chemical Industry Co., Ltd. (Toyama, Japan). SP600125 and LY294002 were purchased from A.G. Scientific, Inc. (San Diego, CA, USA). Antibodies against CCAAT/enhancer-binding protein (C/EBP) homologous protein (CHOP), Akt1/2/3 (phospho Tyr315/316/312) and phosphorylated c-Jun $\mathrm{NH}_{2}$-terminal protein kinase (JNK) were obtained from Santa Cruz Biotechnology, Inc. (Santa Cruz, CA, USA)., and antibody against phosphorylated Akt1/2/3 from Assay Designs (Ann Arbor, MI, USA). Antibodies against MCP-1, VEGF 120 , IL-10, JNK, and anti-glucose-regulated protein (GRP78)/binding immunoglobulin protein (Bip) were obtained from R\&D Systems (Minneapolis, MN, USA), and $\mathrm{N}$-acetyl-cysteine (NAC), hydrogen peroxide $\left(\mathrm{H}_{2} \mathrm{O}_{2}\right)$, and the antibody against $\beta$-Actin from Sigma-Aldrich (St. Louis, MO, USA).

\subsection{Preparation of MIN6 Cells}

Mouse MIN6 pancreatic $\beta$-cells were grown in DMEM (high glucose, without sodium pyruvate) containing $25 \mathrm{mmol} / \mathrm{L}$ glucose supplemented with $15 \%$ fetal calf serum (FCS), $50 \mathrm{U} / \mathrm{mL}$ penicillin, $50 \mu \mathrm{g} / \mathrm{mL}$ L-glutamine, $10 \mu \mathrm{l} / \mathrm{L}$ 2-mercaptoethanol, and $100 \mathrm{mmol} / \mathrm{L}$ sodium pyruvate in a humidified atmosphere containing $5 \%$ of $\mathrm{CO}_{2}$ at $37^{\circ} \mathrm{C}$. At confluence, the cells were used for experiments. 


\subsection{Treatment of MIN6 Cells}

XF Palmitate-BSA FAO Substrate (Seahorse Bioscience) was dissolved in an FCS-free medium, then the final concentration of palmitate in the medium was adjusted to $0.3 \mathrm{mmol} / \mathrm{L}$. At $20 \mathrm{~min}$ before palmitate stimulation, $10 \mu \mathrm{mol} / \mathrm{L}$ astaxanthin, $1 \mathrm{mmol} / \mathrm{L} \mathrm{NAC,} 10 \mu \mathrm{mol} / \mathrm{L} \mathrm{SP600125,} \mathrm{or} 10 \mu \mathrm{mol} / \mathrm{L}$ LY294002 was added in the culture medium. At $24 \mathrm{~h}$ after the exposure to palmitate, the cell lysates and medium were subjected to various experiments.

In other experimental series, MIN6 cells were pretreated with astaxanthin, and then after $20 \mathrm{~min}$, $0.3 \mathrm{mmol} / \mathrm{L} \mathrm{H}_{2} \mathrm{O}_{2}$ was added into the culture medium. At $24 \mathrm{~h}$ after $\mathrm{H}_{2} \mathrm{O}_{2}$ administration, MCP- 1 and $\mathrm{VEGF}_{120}$ secretion were analyzed by immunoblotting.

\subsection{Immunoblotting}

MIN6 cells were lysed in SDS sample buffer containing 1\% Phosphatase Inhibitor Cocktail (Nacalai Tesque, Kyoto, Japan), were sonicated, and centrifuged. The resulting supernatants were boiled in the presence of $50 \mathrm{mmol} / \mathrm{L}$ dithiothreitol. To measure secreted proteins, the supernatant of the culture medium with the cells was also boiled in SDS sample buffer containing 1\% Phosphatase Inhibitor Cocktail with $50 \mathrm{mmol} / \mathrm{L}$ dithiothreitol. Boiled samples were subjected to SDS PAGE, and transferred onto polyvinylidene difluoride membranes (Bio Craft, Tokyo, Japan). Membranes were incubated with primary antibodies as described in the section Reagents, and thereafter with horseradish peroxidase-conjugated secondary antibody. Protein bands were visualized with chemiluminescence reagents according to the manufacturer's protocol (Amersham, Little Chalfont, Buckinghamshire, UK). Bands were scanned and analyzed with NIH Image software. Protein band intensities under basal conditions were set to $100 \%$ for normalization purposes.

\subsection{Real-Time Quantitative PCR}

Using the RNA queous ${ }^{\circledR}-4$ PCR kit (Ambion, Austin, TX, USA), total RNA was extracted from MIN6 cells according to the manufacturer's instructions, and then was reverse-transcribed to cDNA. Real-time quantitative PCR was conducted using the 7300 real-time PCR system (Applied Biosystems, Foster City, CA, USA). The following primers and probes were ordered from Applied Biosystems: VEGF-A (Mm03015192_m1) and MCP-1 (Mm00441242_m1). The mRNA signal was normalized to the $18 \mathrm{~S}$ rRNA signal. The mean value of triplicates was used for comparison of mRNA levels.

\subsection{Quantstudio 3D dPCR}

Total RNA was extracted by the RNAqueous ${ }^{\circledR}$-4PCR kit (Ambion, Austin, TX, USA), then was used to synthesize cDNA. The cDNA was analyzed by the ${ }^{\mathrm{TM}}$ QuantStudio ${ }^{\circledR}$ 3D Digital PCR System (Thermo Fisher Scientific, Waltham, MA, USA). The cDNA was first loaded onto the chips using the QuantStudio ${ }^{\circledR}$ 3D Digital PCR Chip Loader with a mixture comprising $2 \times$ Quantstudio ${ }^{\circledR}$ 3D digital PCR mastermix, and also $300 \mathrm{nmol} / \mathrm{L}$ of GRP78 primers and probes (Mm00517691_m1; Applied Biosystems, Foster City, CA, USA). Next, the chips were sealed and loaded onto a GeneAMPR PCR system 9700 (Applied Biosystems, Foster City, CA, USA), and then the following cycling conditions were used: $96^{\circ} \mathrm{C}$ for $10 \mathrm{~min}$, followed by 39 cycles of $60^{\circ} \mathrm{C}$ for $2 \mathrm{~min}$ and $98^{\circ} \mathrm{C}$ for $30 \mathrm{~s}$, and a final extension at $60^{\circ} \mathrm{C}$ for $2 \mathrm{~min}$. Finally, the end-point fluorescence of the segmentation processes on the chips was analyzed by transferring the chips to the measurement unit (application version 1.1.3, algorithm version 0.13, Applied Biosystems, Foster City, CA, USA). In addition, the mRNA signal of GRP78 was normalized to18S rRNA.

\subsection{Quantification of Hydroperoxides}

MIN6 cells were incubated as discussed previously, supernatants were removed, and the cells were washed three times with PBS. The cells were lysed in a buffer consisting of $0.5 \mathrm{mmol} / \mathrm{L}$ Tris- $\mathrm{HCl}$ (pH 7.4), $1.5 \mathrm{mmol} / \mathrm{L} \mathrm{NaCl}, 2.5 \%$ deoxycholic acid, and 10\% Nonidet P-40. Lysates were centrifuged for 
$10 \mathrm{~min}$ at $15,000 \mathrm{~g}$ and $4{ }^{\circ} \mathrm{C}$; the supernatants were assayed for intracellular endogenous hydroperoxides by the Free Radical Elective Evaluator system (Diacron, Grosseto, Italy) according to the manufacturer's protocol. Hydroperoxide units of Carratelli units were adjusted to intracellular total protein contents.

\subsection{Statistical Analysis}

Statistical analysis was performed by unpaired $t$-test or by analysis of variance (ANOVA). Results are expressed as mean \pm SEM and $p<0.05$ was considered statistically significant.

Supplementary Materials: The following are available online at www.mdpi.com/1660-3397/15/6/185/s1. Figure S1. Palmitate $(0.3 \mathrm{mmol} / \mathrm{L})$ can not induce endoplasmic reticulum stress in hypertrophied 3T3-L1 adipocytes, in contrast to in MIN6 $\beta$-cells. Mature 3T3-L1 adipocyte were preloaded with $0.3 \mathrm{mmol} / \mathrm{L}$ palmitate or ethanol vehicle alone for $24 \mathrm{~h}(\mathrm{~A}, \mathrm{~B})$. A and B: Intraceller CHOP (a) and GRP78 (b) protein content were quantified by immunoblot analysis. $\beta$-Actin served as an internal control. Results are means $\pm \mathrm{SE}(\mathrm{n}=4)$. ${ }^{* *} p<0.01$ compared to vehicle. NS; no significant difference compared to vehicle.

Acknowledgments: This study was supported by Grants-in-Aid for Scientific Research from the Ministry of Education, Science and Culture to Hitoshi Ishida (16k09811) and Kazuto Takahashi (15k01725) and by a grant from the Japan Private School Promotion Foundation.

Author Contributions: Kazuto Takahashi, Atsuko Kitahara, Takuma Kondo and Hitoshi Ishida conceived and designed the experiments; Atsuko Kitahara performed the experiments; Toshitaka Murashima and Naru Morita analyzed the data; Toshio Hosaka, Toshiaki Tanaka, Yoshikazu Sumitani, Hirohisa Onuma, Takuma Kondo contributed reagents/materials/analysis tools; Kazuto Takahashi, Atsuko Kitahara and Hitoshi Ishida wrote the paper.

Conflicts of Interest: The authors declare no conflict of interest.

\section{References}

1. Ambati, R.R.; Phang, S.M.; Ravi, S.; Aswathanarayana, R.G. Astaxanthin: Sources, extraction, stability, biological activities and its commercial applications-a review. Mar. Drugs 2014, 12, 128-152. [CrossRef] [PubMed]

2. Wolf, A.M.; Asoh, S.; Hiranuma, H.; Ohsawa, I.; Iio, K.; Satou, A.; Ishikura, M.; Ohta, S. Astaxanthin protects mitochondrial redox state and functional integrity against oxidative stress. J. Nutr. Biochem. 2010, 21, 381-389. [CrossRef] [PubMed]

3. Aoi, W.; Naito, Y.; Takanami, Y.; Ishii, T.; Kawai, Y.; Akagiri, S.; Kato, Y.; Osawa, T.; Yoshikawa, T. Astaxanthin improves muscle lipid metabolism in exercise via inhibitory effect of oxidative CPT I modification. Biochem. Biophys. Res. Commun. 2008, 366, 892-897. [CrossRef] [PubMed]

4. Ikeuchi, M.; Koyama, T.; Takahashi, J.; Yazawa, K. Effects of astaxanthin supplementation on exercise-induced fatigue in mice. Biol. Pharm. Bull. 2006, 29, 2106-2110. [CrossRef] [PubMed]

5. Kishimoto, Y.; Tani, M.; Uto-Kondo, H.; Iizuka, M.; Saita, E.; Sone, H.; Kurata, H.; Kondo, K. Astaxanthin suppresses scavenger receptor expression and matrix metalloproteinase activity in macrophages. Eur. J. Nutr. 2010, 49, 119-126. [CrossRef] [PubMed]

6. Li, W.; Hellsten, A.; Jacobsson, L.S.; Blomqvist, H.M.; Olsson, A.G.; Yuan, X.M. Alpha-tocopherol and astaxanthin decrease macrophage infiltration, apoptosis and vulnerability in atheroma of hyperlipidaemic rabbits. J. Mol. Cell. Cardiol. 2004, 37, 969-978. [CrossRef] [PubMed]

7. Ni, Y.; Nagashimada, M.; Zhuge, F.; Zhan, L.; Nagata, N.; Tsutsui, A.; Nakanuma, Y.; Kaneko, S.; Ota, T. Astaxanthin prevents and reverses diet-induced insulin resistance and steatohepatitis in mice: A comparison with vitamin E. Sci. Rep. 2015, 5, 17192. [CrossRef] [PubMed]

8. Suzuki, Y.; Ohgami, K.; Shiratori, K.; Jin, X.H.; Ilieva, I.; Koyama, Y.; Yazawa, K.; Yoshida, K.; Kase, S.; Ohno, S. Suppressive effects of astaxanthin against rat endotoxin-induced uveitis by inhibiting the NF-kappaB signaling pathway. Exp. Eye Res. 2006, 82, 275-281. [CrossRef] [PubMed]

9. Nakajima, Y.; Inokuchi, Y.; Shimazawa, M.; Otsubo, K.; Ishibashi, T.; Hara, H. Astaxanthin, a dietary carotenoid, protects retinal cells against oxidative stress in vitro and in mice in vivo. J. Pharm. Pharmacol. 2008, 60, 1365-1374. [CrossRef] [PubMed] 
10. Yoon, H.S.; Cho, H.H.; Cho, S.; Lee, S.R.; Shin, M.H.; Chung, J.H. Supplementating with dietary astaxanthin combined with collagen hydrolysate improves facial elasticity and decreases matrix metalloproteinase-1 and -12 expression: A comparative study with placebo. J. Med. Food 2014, 17, 810-816. [CrossRef] [PubMed]

11. Uchiyama, K.; Naito, Y.; Hasegawa, G.; Nakamura, N.; Takahashi, J.; Yoshikawa, T. Astaxanthin protects beta-cells against glucose toxicity in diabetic db/db mice. Redox Rep. 2002, 7, 290-293. [CrossRef] [PubMed]

12. Arunkumar, E.; Bhuvaneswari, S.; Anuradha, C.V. An intervention study in obese mice with astaxanthin, a marine carotenoid-effects on insulin signaling and pro-inflammatory cytokines. Food Funct. 2012, 3, 120-126. [CrossRef] [PubMed]

13. Bhuvaneswari, S.; Anuradha, C.V. Astaxanthin prevents loss of insulin signaling and improves glucose metabolism in liver of insulin resistant mice. Can. J. Physiol. Pharmacol. 2012, 90, 1544-1552. [CrossRef] [PubMed]

14. Ishiki, M.; Nishida, Y.; Ishibashi, H.; Wada, T.; Fujisaka, S.; Takikawa, A.; Urakaze, M.; Sasaoka, T.; Usui, I.; Tobe, K. Impact of divergent effects of astaxanthin on insulin signaling in L6 cells. Endocrinology 2013, 154, 2600-2612. [CrossRef] [PubMed]

15. Weisberg, S.P.; McCann, D.; Desai, M.; Rosenbaum, M.; Leibel, R.L.; Ferrante, A.W. Obesity is associated with macrophage accumulation in adipose tissue. J. Clin. Investig. 2003, 112, 1796-1808. [CrossRef] [PubMed]

16. Xu, H.; Barnes, G.T.; Yang, Q.; Tan, G.; Yang, D.; Chou, C.J.; Sole, J.; Nichols, A.; Ross, J.S.; Tartaglia, L.A.; et al. Chronic inflammation in fat plays a crucial role in the development of obesity-related insulin resistance. J. Clin. Investig. 2003, 112, 1821-1830. [CrossRef] [PubMed]

17. Sartipy, P.; Loskutoff, D.J. Monocyte chemoattractant protein 1 in obesity and insulin resistance. Proc. Natl. Acad. Sci. USA 2003, 100, 7265-7270. [CrossRef] [PubMed]

18. Kawamura, T.; Murakami, K.; Bujo, H.; Unoki, H.; Jiang, M.; Nakayama, T.; Saito, Y. Matrix metalloproteinase-3 enhances the free fatty acids-induced VEGF expression in adipocytes through toll-like receptor 2. Exp. Biol. Med. (Maywood) 2008, 233, 1213-1221. [CrossRef] [PubMed]

19. Miyazawa-Hoshimoto, S.; Takahashi, K.; Bujo, H.; Hashimoto, N.; Yagui, K.; Saito, Y. Roles of degree of fat deposition and its localization on VEGF expression in adipocytes. Am. J. Physiol. Endocrinol. Metab. 2005, 288, e1128-e1136. [CrossRef] [PubMed]

20. Takahashi, K.; Miyokawa-Gorin, K.; Handa, K.; Kitahara, A.; Moriya, R.; Onuma, H.; Sumitani, Y.; Tanaka, T.; Katsuta, H.; Nishida, S.; et al. Endogenous oxidative stress, but not ER stress, induces hypoxia-independent VEGF120 release through PI3K-dependent pathways in 3T3-L1 adipocytes. Obesity 2013, 21, 1625-1634. [CrossRef] [PubMed]

21. Kamei, N.; Tobe, K.; Suzuki, R.; Ohsugi, M.; Watanabe, T.; Kubota, N.; Ohtsuka-Kowatari, N.; Kumagai, K.; Sakamoto, K.; Kobayashi, M.; et al. Overexpression of monocyte chemoattractant protein-1 in adipose tissues causes macrophage recruitment and insulin resistance. J. Biol. Chem. 2006, 281, 26602-26614. [CrossRef] [PubMed]

22. Kanda, H.; Tateya, S.; Tamori, Y.; Kotani, K.; Hiasa, K.; Kitazawa, R.; Kitazawa, S.; Miyachi, H.; Maeda, S.; Egashira, K.; et al. MCP-1 contributes to macrophage infiltration into adipose tissue, insulin resistance, and hepatic steatosis in obesity. J. Clin. Investig. 2006, 116, 1494-1505. [CrossRef] [PubMed]

23. Nishimura, S.; Manabe, I.; Nagasaki, M.; Hosoya, Y.; Yamashita, H.; Fujita, H.; Ohsugi, M.; Tobe, K.; Kadowaki, T.; Nagai, R.; et al. Adipogenesis in obesity requires close interplay between differentiating adipocytes, stromal cells, and blood vessels. Diabetes 2007, 56, 1517-1526. [CrossRef] [PubMed]

24. Manukyan, L.; Ubhayasekera, S.J.; Bergquist, J.; Sargsyan, E.; Bergsten, P. Palmitate-induced impairments of $\beta$-cell function are linked with generation of specific ceramide species via acylation of sphingosine. Endocrinology 2015, 156, 802-812. [CrossRef] [PubMed]

25. Barlow, J.; Jensen, V.H.; Jastroch, M.; Affourtit, C. Palmitate-induced impairment of glucose-stimulated insulin secretion precedes mitochondrial dysfunction in mouse pancreatic islets. Biochem. J. 2016, 473, 487-496. [CrossRef] [PubMed]

26. Takahashi, K.; Yamaguchi, S.; Shimoyama, T.; Seki, H.; Miyokawa, K.; Katsuta, H.; Tanaka, T.; Yoshimoto, K.; Ohno, H.; Nagamatsu, S.; et al. JNK- and IkappaB-dependent pathways regulate MCP-1 but not adiponectin release from artificially hypertrophied 3T3-L1 adipocytes preloaded with palmitate in vitro. Am. J. Physiol. Endocrinol. Metab. 2008, 294, 898-909. [CrossRef] [PubMed] 
27. Kitahara, A.; Takahashi, K.; Moriya, R.; Onuma, H.; Handa, K.; Sumitani, Y.; Tanaka, T.; Katsuta, H.; Nishida, S.; Sakurai, T.; et al. Ghrelin augments the expressions and secretions of proinflammatory adipokines, VEGF120 and MCP-1, in differentiated 3T3-L1 adipocytes. J. Cell. Physiol. 2015, 230, 199-209. [CrossRef] [PubMed]

28. Bhuvaneswari, S.; Yogalakshmi, B.; Sreeja, S.; Anuradha, C.V. Astaxanthin reduces hepatic endoplasmic reticulum stress and nuclear factor- $\kappa \mathrm{B}-$ mediated inflammation in high fructose and high fat diet-fed mice. Cell Stress Chaperones 2014, 19, 183-191. [CrossRef] [PubMed]

29. Sargsyan, E.; Artemenko, K.; Manukyan, L.; Bergquist, J.; Bergsten, P. Oleate protects beta-cells from the toxic effect of palmitate by activating pro-survival pathways of the ER stress response. Biochim. Biophys. Acta 2016, 1861, 1151-1160. [CrossRef] [PubMed]

30. Lai, E.; Bikopoulos, G.; Wheeler, M.B.; Rozakis-Adcock, M.; Volchuk, A. Differential activation of ER stress and apoptosis in response to chronically elevated free fatty acids in pancreatic beta-cells. Am. J. Physiol. Endocrinol. Metab. 2008, 294, 540-550. [CrossRef] [PubMed]

31. Cnop, M.; Ladrière, L.; Igoillo-Esteve, M.; Moura, R.F.; Cunha, D.A. Causes and cures for endoplasmic reticulum stress in lipotoxic $\beta$-cell dysfunction. Diabetes Obes. Metab. 2010, 12, 76-82. [CrossRef] [PubMed]

32. Lu, H.; Hao, L.; Li, S.; Lin, S.; Lv, L.; Chen, Y.; Cui, H.; Zi, T.; Chu, X.; Na, L.; et al. Elevated circulating stearic acid leads to a major lipotoxic effect on mouse pancreatic beta cells in hyperlipidaemia via a miR-34a-5p-mediated PERK/p53-dependent pathway. Diabetologia 2016, 59, 1247-1257. [CrossRef] [PubMed]

33. Hasnain, S.Z.; Prins, J.B.; McGuckin, M.A. Oxidative and endoplasmic reticulum stress in $\beta$-cell dysfunction in diabetes. J. Mol. Endocrinol. 2016, 56, 33-54. [CrossRef] [PubMed]

34. Fonseca, S.G.; Gromada, J.; Urano, F. Endoplasmic reticulum stress and pancreatic $\beta$-cell death. Trends Endocrinol. Metab. 2011, 22, 266-274. [CrossRef] [PubMed]

35. Teodoro-Morrison, T.; Schuiki, I.; Zhang, L.; Belsham, D.D.; Volchuk, A. GRP78 overproduction in pancreatic beta cells protects against high-fat-diet-induced diabetes in mice. Diabetologia 2013, 56, 1057-1067. [CrossRef] [PubMed]

36. Robertson, R.P.; Harmon, J.; Tran, P.O.; Poitout, V. Beta-cell glucose toxicity, lipotoxicity, and chronic oxidative stress in type 2 diabetes. Diabetes 2004, 53, S119-S124. [CrossRef] [PubMed]

37. Kim, J.W.; Yoon, K.H. Glucolipotoxicity in Pancreatic $\beta$-Cells. Diabetes Metab. J. 2011, 35, 444-450. [CrossRef] [PubMed] 